\title{
Ligninolytic Enzyme Production by White Rot Fungi Podoscypha elegans Strain FTG4
}

\author{
Nikki Agrawal, Preeti Verma, Ravi Shankar Singh and Sushil Kumar Shahi* \\ Bio-resource Tech Laboratory, Department of Botany, Guru Ghasidas Vishwavidyalaya, \\ Bilaspur, Chhattisgarh 495009, India \\ *Corresponding author
}

\begin{tabular}{|c|c|}
\hline & A B S T R A C T \\
\hline $\begin{array}{l}\text { Key w or d s } \\
\text { Podoscypha } \\
\text { elegans, Laccase, } \\
\text { Lignin peroxidase, } \\
\text { Manganese } \\
\text { peroxidase. }\end{array}$ & \multirow{3}{*}{$\begin{array}{l}\text { The aim of this study to investigate the laccase, lignin peroxidase and manganese } \\
\text { peroxidase enzyme production by white rot fungi Podoscypha elegans, A white } \\
\text { rot fungi } P \text {. elegans was collected from the Bilaspur district of Chhattisgarh, India, } \\
\text { then fungi was cultivated in the ligninolytic enzyme screening medium containing } \\
\text { indicator compound, after that quantify the production of enzymes. The maximum } \\
1013 \mathrm{U} / \mathrm{L} \text { laccase, } 48.24 \mathrm{U} / \mathrm{mg} \text { Specific laccase activity, } 1509 \mathrm{U} / \mathrm{L} \text { lignin } \\
\text { peroxidase, } 71.86 \mathrm{U} / \mathrm{mg} \text { Specific lignin peroxidase activity, } 14230 \mathrm{U} / \mathrm{L} \text { manganese } \\
\text { peroxidase, } 677.62 \mathrm{U} / \mathrm{mg} \text { Specific manganese peroxidase activity and } 358 \mathrm{mg} \\
\text { biomass were found in the mineral salt broth. Ligninolytic enzymes are } \\
\text { responsible for the lignin and organic pollutant degradation therefore } P \text {. elegans } \\
\text { can be used for the degradation of pollutants from the environment. }\end{array}$} \\
\hline Article Info & \\
\hline $\begin{array}{l}\text { Accepted: } \\
\text { 26 April } 2017 \\
\text { Available Online: } \\
\text { 10 May } 2017\end{array}$ & \\
\hline
\end{tabular}

\section{Introduction}

The white rot fungi are considered for their unique ability to degrade a heterogenous polyphenolic polymer lignin (Baldrian, 2003; Pointing, 2001). Besides of these, white rot fungi are also able to degrade several other organicpolluttants which are structurally similar to lignin (Tuomela and Hatakka, 2011). White rot fungi produced non-specific extracellular ligninolytic enzymes such as laccase, lignin peroxidase (LiP) and manganese peroxidase (MnP) (Kitamura et $a l ., 2005)$. These ligninolytic enzymes play an important role in the transformation and mineralization of various organic pollutants (Lee et al., 2004; Casas et al., 2009; Wang et al., 2009), delignify different substrates like paper, animal feed (Lu et al., 2010; Salvachua et al., 2011) for the production of biofuels (Placido and Capareda, 2015).

Laccase is a multi copper containing enzyme (EC 1.10.3.2: benzenediol, oxygenoxido reductase or $\mathrm{p}$-diphenol oxidase), catalyze the oxidation of aromatic and non-aromatic substrates by a radical catalyzed mechanism (Claus, 2004). Laccase is involved in the dye decolourization (Dominguez et al., 2005; Hou et al., 2004), food processing (Couto and Herrera, 2006), plant pathogenesis in nature (Geiger et al., 1986) paper and pulp industries, bioremediation and biodegradation (Pointing, 2001), and sporulation in fungi (Leatham and Stahmann, 1981). LiP (EC 1.11.1.14, 1, 2-bis (3,4-dimethoxyphenyl) 
propane-1,3-diol:hydrogen-peroxide oxido reductase) catalyze the hydrogen peroxidase dependent depolymerisation of lignin and other phenol, non-phenolic lignin model compounds (Tien and Kirt, 1983; Hammel et al., 1993). MnP (EC 1.11.1.13 Mn (II): hydrogen-peroxide oxidoreductase) catalyze the Mn dependent reaction (Orth and Tien, 1995). MnP oxidize Mn (II) to Mn (III), which catalyze the oxidation of phenolic compounds, including dyes (Wong, 2009).

The study of ligninolytic enzyme production has been carried out in different white rot fungi such as Ganoderma lucidum, Trametes versicolor, Dichomitussqualens, Phanerochaete chrysosporium, Phlebia fascicularia, Pleurotus ostreatus, Armillaria sp. F022 (Sasidhara et al., 2014; Arora and Gill, 2000; Hadibarata and Kristanti, 2013). But the production of ligninolytic enzyme is less studied in P. elegans. Due to the potential application of ligninolytic enzyme, our aim to study the ligninolytic enzyme production in $P$. elegans, isolated from Bilaspur district of Chhattisgarh, India, for the further use in the process of remediation of organic pollutants.

\section{Materials and Methods}

\section{Chemicals}

Guaiacol, Azure B, 2, 6 - dimethoxy phenol (2, 6 - DMP) was purchased from Himedia, India. All other chemicals and solvents used were of analytical grade purchased from Himedia, India.

\section{Microorganism and culture condition}

A white rot fungi strain FTG4 (Accession no. KY464924.1), was collected from the wood surface from the Bilaspur district of Latitude $22^{\circ} 77^{\prime} 50.1204^{\prime \prime}$, Longitude $82^{\circ} 8^{\prime} 31.2252^{\prime \prime}$ and Elevation 280.0 meters) Chhattisgarh, India, fungi were isolated from the fruiting body by the spore drop method according to Choi et al., 1999. A piece of fruiting body was cut and transferred in the top of a petri dish containing Sabouraud Dextrose Agar (SDA) media composition (g/L): Dextrose (40), Peptone (10), Agar (15) and streptomycin $(500 \mathrm{mg} / \mathrm{L})$ antibiotic to inhibit the bacterial growth) then incubate at $27^{\circ} \mathrm{C}$, once the pure culture was obtained, culture was maintained in SDA media prior to use and stored at $4^{\circ} \mathrm{C}$. On the basis of morphological identification and molecular characterization through $18 \mathrm{~S}$ rRNA cultured fungi are the member of family Podoscyphaceae and show 99\% similarity to the genus Podoscypha.

\section{Qualitative screening for ligninolytic enzyme}

The ability of the white rot fungi P. elegans to secrete extracellular ligninolytic enzyme was screened on the basis of oxidation of indicator compound in the screening medium. The method of enzyme production is as follows:

\section{Laccase enzyme activity}

To access laccase assay $6 \mathrm{~mm}$ diameter one fungal disc (taken from the periphery of the 7 day old cultures grown in SDA media) of FTG4 strain was transferred on the petri dish (15 $\mathrm{cm}$ in diameter) containing $25 \mathrm{~mL}$ of Potato dextrose agar media (PDA g/L: Potato infusion - 200, Dextrose - 20, Agar - 20) with $0.01 \%$ Guaiacol (D'Souza et al., 2006). After that Plates were incubated at $27^{\circ} \mathrm{C}$ for 7 days in a static incubator and the change in the colour of the media around the mycellium was investigated.

\section{Lignin peroxidase enzyme activity}

Lignin Peroxidase screening medium $(\mathrm{g} / \mathrm{L}$ : Glucose - 4.0, Glycerol - 0.7, L histidine $0.05, \mathrm{CuSO}_{4}-0.01, \mathrm{NaNO}_{3}-0.18, \mathrm{NaCl}-$ $0.18, \mathrm{KCl}-0.05, \mathrm{CaCl}_{2} \cdot \mathrm{H}_{2} \mathrm{O}-0.05, \mathrm{KH}_{2} \mathrm{PO}_{4}-$ $0.1, \mathrm{FeSO}_{4} \cdot \mathrm{H}_{2} \mathrm{O}-0.005, \mathrm{MgSO}_{4} \cdot 7 \mathrm{H}_{2} \mathrm{O}-0.05$, Guaiacol - $10 \mathrm{mM}(\mathrm{v} / \mathrm{v}), \mathrm{H}_{2} \mathrm{O}_{2}-10 \mathrm{mM}$, 
Agar - 2.0) was used for the lignin peroxidase enzyme assay. $6 \mathrm{mM}$ diameter of fungal disc was transferred in the LiP screening medium, then incubated for 7 days and the colour change in the screening medium was analyzed (Atalla et al., 2010; Sivakami et al., 2012).

\section{Manganese peroxidase enzyme activity}

To access MnP enzyme activity Czapek-Dox agar medium containing $0.0025 \%$ phenol red (w/v) was employed (Kuwahara et al., 1984; Ali et al., 2012). Fungal strain FTG4 (6 mm diameter one fungal disc) was inoculated in the Czapek-Dox agar medium at $27^{\circ} \mathrm{C}$ for 7 days and colour zone produced in the screening medium was analyzed.

\section{Quantitative estimation of ligninolytic enzyme production}

To estimate the enzyme production in $P$. elegans, $8 \mathrm{~mm}$ fungal mycelium disc was transferred in the $20 \mathrm{~mL}$ mineral salt broth (composition g/L: Glucose - 10, $\mathrm{KH}_{2} \mathrm{PO}_{4}-2$, $\mathrm{MgSO}_{4} \cdot 7 \mathrm{H}_{2} \mathrm{O}-0.5, \mathrm{CaCl}_{2} \cdot 2 \mathrm{H}_{2} \mathrm{O}-0.1$, Ammonium tartrate -0.2 and Trace element solution $-10(\mathrm{~mL})$. A trace element solution comprised of (in $\mathrm{mg} / \mathrm{L}$ ) $\mathrm{FeSO}_{4} \cdot 7 \mathrm{H}_{2} \mathrm{O}$ (12), $\mathrm{MnSO}_{4} \cdot 7 \mathrm{H}_{2} \mathrm{O} \quad$ (3), $\quad \mathrm{ZnSO}_{4} \cdot 7 \mathrm{H}_{2} \mathrm{O} \quad$ (3), $\mathrm{CoSO}_{4} \cdot 7 \mathrm{H}_{2} \mathrm{O}$ (1), (NH4) ${ }_{6} \mathrm{Mo}_{7} \mathrm{O}_{24} \cdot 4 \mathrm{H}_{2} \mathrm{O}$ (1) (Hadibarata and Kristanti, 2012). Then incubate the culture at $27^{\circ} \mathrm{C}$ in a rotatory shaker incubator for $2,4,6,8,10,12,14,16$, 18 and 20 days, after that enzyme production was analyzed. All the experiments were performed in triplicates. The production of ligninolytic enzyme was investigated as the following procedure:

\section{Laccase assay}

For the laccase enzyme production, take $3 \mathrm{~mL}$ of reaction mixture containing $0.5 \mathrm{~mL}$ of the enzyme extract, $1.5 \mathrm{~mL}$ sodium acetate buffer (10 mM, pH 5.0) and $1 \mathrm{~mL}$ guaiacol $(2 \mathrm{mM})$, then incubated for $2 \mathrm{~h}$ and absorbance read at $450 \mathrm{~nm}$. The laccase enzyme activity has been expressed in international units per liter of enzyme extract (U/L) (Sandhu and Arora, 1985).

\section{Lignin peroxidase assay}

To investigate the lignin peroxidase enzyme production, take $0.5 \mathrm{~mL}$ of the culture filtrate, $1 \mathrm{~mL}$ of $125 \mathrm{mM}$ sodium tartrate buffer $(\mathrm{pH}$ 3.0 ), $0.5 \mathrm{~mL}$ of $0.16 \mathrm{mM}$ azure $\mathrm{B}$, then add $0.5 \mathrm{~mL}$ of $2 \mathrm{mM}$ hydrogen peroxide, after addition of hydrogen peroxide, the reaction was initiated. One unit of enzyme activity was expressed as an O.D. decrease at $651 \mathrm{~nm}$ of 0.1 units per minute per litre of the culture filtrate Archibald (1992).

\section{Manganese peroxidase assay}

According to de Jong et al., (1992) manganese peroxidase activity was accessed by the oxidation of 2,6 - DMP at $468 \mathrm{~nm}$. Take and $3 \mathrm{~mL}$ of reaction mixture contained $0.5 \mathrm{~mL}$ culture filtrate, $1 \mathrm{~mL}$ of sodium tartrate buffer (50 mM, pH 4.0) and $1 \mathrm{~mL}$ of 2 $\mathrm{mM}$ 2, 6-DMP. The reaction was started by the addition of $0.5 \mathrm{~mL}$ of $0.4 \mathrm{mM}$ hydrogen peroxide.

\section{Results and Discussion}

Qualitative screening for the ligninolytic enzyme activity

\section{Laccase assay}

On the basis of qualitative screening it was investigated that fungi $P$. elegans having the ability to produce ligninolytic enzyme. Due to oxidation of guaiacol by laccase enzyme, $70.00 \mathrm{~mm}$ diameter intense red colour zone (Fig. 1 a) appeared around the mycelium. Guaiacol is a very sensitive chromogenic compound, used for the screening of the production of enzymes on the basis of their oxidation reaction (Kiiskinen et al., 2004). Similarly Atalla et al., 2010 also screened the 
fungi on the basis of their oxidizing property, found that Pleurotus ostreatus and Trematosphaeria mangrovei showed 32.00 $\mathrm{mm}$ reddish brown colour zone due to oxidation of guaiacol.

\section{LiP assay}

The production of LiP enzyme by $P$. elegans fungi was screened in the $\mathrm{LiP}$ screening medium.

After the oxidation of guaiacol by $\mathrm{LiP}$ enzyme in the presence of hydrogen peroxide in the LiP screening medium $70.00 \mathrm{~mm}$ diameter brick red colour zone (Fig. 1 b) appeared.

\section{MnP assay}

In the MnP enzyme assay, due to the oxidation of phenol red by MnP enzyme the formation of yellow colour zone was investigated. Fig. $1 \mathrm{c}$ showed that $50.00 \mathrm{~mm}$ diameter yellow colour zone (Fig. 1 c) appeared around the mycelium.

\section{Production of ligninolytic enzyme}

The production of ligninolytic enzyme was investigated in the fungal strain FTG4 after 2, $4,6,8,10,12,14,16,18$ and 20 days of incubation in mineral salt broth. As the incubation period increases, the ligninolytic enzyme production also increases in the fungal strain FTG4.

Fig.1 Qualitative screening for ligninolytic enzyme in FTG4 fungal strain, a - Laccase (red colour zone), b - Lignin peroxidase (reddish brown zone), and c - Manganese peroxidase (yellow colour zone) production by fungal strain FTG4
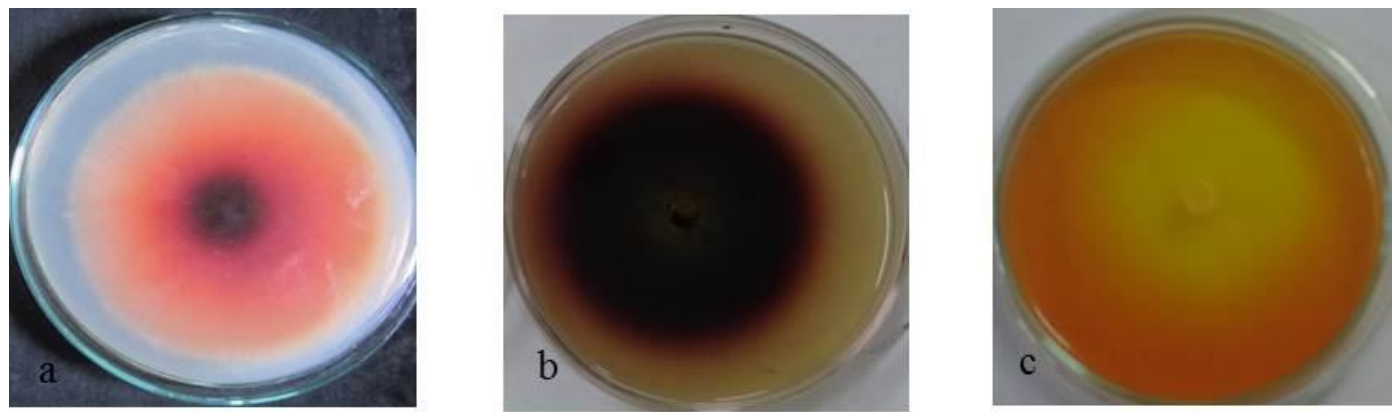

Fig.2 Laccase enzyme production by $P$. elegans

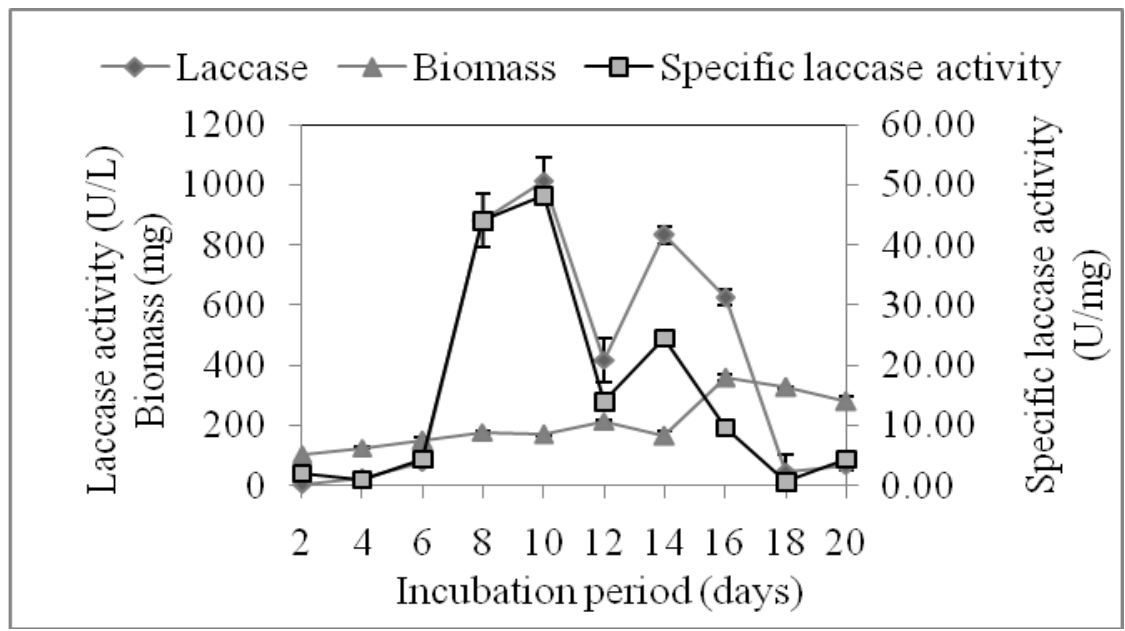

Fig.3 LiP enzyme production by P. elegans 


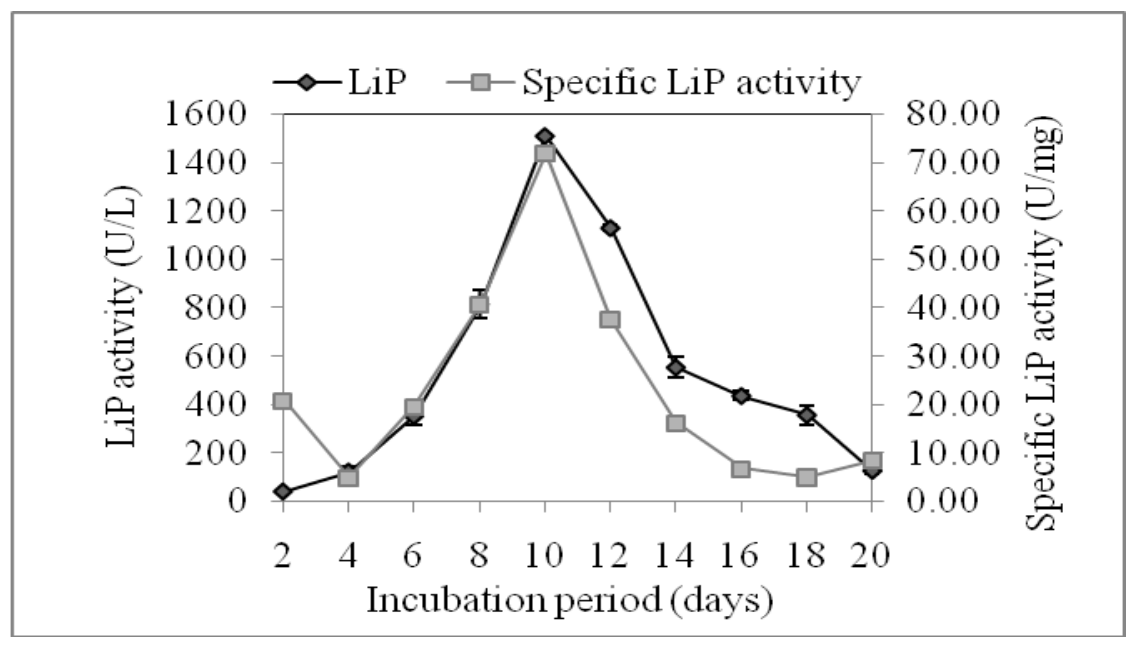

Fig.4 MnP enzyme production by $P$. elegans

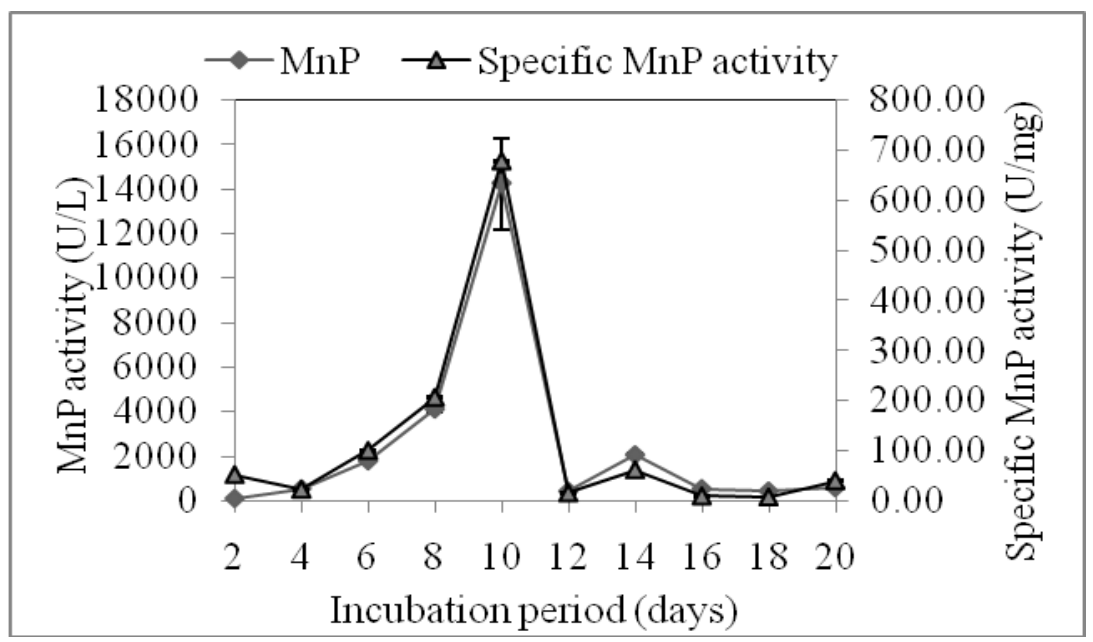

\section{Laccase enzyme production}

The production of laccase enzyme rose to a maximum after 8-10 days of incubation, at $10^{\text {th }}$ day maximum $1013 \mathrm{U} / \mathrm{L}$ laccase enzyme production was investigated (Fig. 2), and then decreased, again increased, and after 20 days $66.73 \mathrm{U} / \mathrm{L}$ laccase enzyme activity was found. The maximum $48.24 \mathrm{U} / \mathrm{mg}$ Specific laccase activity was investigated after 10 days of incubation (Fig. 2).

\section{LiP enzyme production}

LiP enzyme production was investigated by the oxidizing property of LiP enzyme, it oxidizes Azure B in the presence of hydrogen peroxidase, the change in the absorbance was read at $651 \mathrm{~nm}$. After the $10^{\text {th }}$ day of incubation maximum 1509 U/L LiP enzyme activity was found, and then the activity of LiP enzyme decreases and71.86 U/mg Specific LiP activity was investigated (Fig. $3)$.

\section{MnP enzyme production}

The oxidation of 2, 6 DMP by MnP enzyme is a suitable method to quantify for the $\mathrm{MnP}$ enzyme. The maximum $14230 \mathrm{U} / \mathrm{L} \mathrm{MnP}$, $677.62 \mathrm{U} / \mathrm{mg}$ Specific MnP activity was found (Fig. 4).

In this study it was found that $P$. elegans produced efficient amount of ligninolytic 
enzyme. Therefore, we can use $P$. elegans for the remediation of organic pollutants, because many researchers (Bogan and Lamar, 1995; Hadibarata and Tachibana, 2010) also suggested that ligninolytic enzyme plays a significant role in the degradation of organic pollutants.

In conclusion, in this study ligninolytic enzyme producing white rot fungi $P$. elegans strain FTG4 was isolated. $P$. elegans produced efficient amount of enzyme in the mineral salt broth, therefore $P$. elegans can be used for the organic pollutant degradation study after successful investigation.

\section{Acknowledgements}

The authors are thankful to Mr. Anand Barapatre, SRF (Department of Occupational Health) JNARDDC Campus, Nagpurto improve my research work. The authors are also thankful to Head, Department of Botany, Guru Ghasidas Vishwavidyalaya, providing infrastructural facilities. Also, thank to Guru GhasidasVishwavidyalaya, Bilaspur (C.G.) for providing financial assistance.

\section{References}

Ali, M.I.A., Khalil, N.M., and El-Ghany, M.N.A. 2012. Biodegradation of some polycyclic aromatic hydrocarbons by Aspergillusterreus. African J. Microbiol. Res., 6: 3783-3790.

Archibald, F.S. 1992. A new assay for lignin type peroxidase employing the dye Azure B. Appl. Environ. Microbiol., 58: 3110-3116.

Arora, D.S., and Gill, P.K. 2000. Laccase production by some white rot fungi under different nutritional conditions. Biores. Technol., 73: 283-285.

Atalla, M.M., Zeinab, H.K., Eman, R.H., Amani, A.Y., andAbeer, A.A.A. 2010. Screening of some marine-derived fungal isolates for lignin degrading enzymes (LDEs) production. Agri. Biol. J. North America, 1: 591-599.

Baldrian, P. 2003. Interactions of heavy metals with white-rot fungi. Enzyme and Microbial Technol., 32: 78-91.

Bogan, B., and Lamar, R.T. 1996. Polycyclic aromatic hydrocarbon degrading capabilities of Phanerochaetelaevis HHB-1625 and its extracellular ligninolytic enzymes. Appl. Environ. Microbiol., 62: 1597-1603.

Casas, N., Parella, T., Vicent, T., Caminal, G., and Sarra, M. 2009. Metabolites from the biodegradation of triphenylmethane dyes by Trametesversicolor or laccase. Chemosphere, 75: 1344-1349.

Choi, Y.W., Hyde, K.D., and Ho, W.H. 1999. Single spore isolation of fungi. Fungal Divers, 3: 29-38.

Claus, H. 2004. Laccases: structure, reactions, distribution. Micron, 35: 93-96.

Couto, S.R., and Herrera, J.L.T. 2006. Industrial and biotechnological applications of laccases: a review. Biotechnol. Adv., 24(5): 500-513.

D’Souza, D.T., Tiwari, R., Sah, A.K., and Raghukumar, C. 2006. Enhanced production of laccase by a marine fungus during treatment of colored effluent and synthetic dyes. Enzyme and Microbial Technol., 38: 504-511.

de Jong, Ed., Field, J.A., and de Bont, J.A.1992. Evidence for a new extracellular peroxidase manganese inhibited peroxidase from the white rot fungus Bjerkandera sp. BOS 55. FEBS Lett., 299: 107-110.

Dominguez, A., Couto, S. R., and Sanroman, M.A. 2005. Dye decolorization by Trameteshirsuta immobilized into alginate beads. World J. Microbio. Biotechnol., 21(4): 405-409.

Geiger, J.P., Nicole, M., Nandris, D., and Rio, B. 1986. Root rot diseases of Heveabrasiliensis I. Physiological and 
biochemical aspects of root aggression. Forest Pathol., 16: 22-37.

Hadibarata, T., and Tachibana, S. 2010.Characterization of phenanthrene degradation by strainPolyporus $\mathrm{sp}$. S133. J. Environ. Sci., 22: 142-149.

Hadibarata, T., and Kristanti, R.A. 2013. Biodegradation and metabolite transformation of pyrene by basidiomycetes fungal isolate Armillaria sp. F022. Bioprocess and Biosystem Engi., 36: 461-468.

Hadibarata, T., and Kristanti, R.A. 2012. Fate and cometabolic degradation of benzo[a]pyrene by white rot fungus Armillaria sp. F022. Biores. Technol., 107: 314-318.

Hammel, K.E., Jensen, Jr., K.A., Mozuch, M. D., Landucci, L.L., Tien, M., and Pease, E.A. 1993. Ligninolysis by a purified lignin peroxidase. J. Biol. Chem., 268: 12274-12281.

Heinzkill, M., Bech, L., Halkier, T., Schneider, P., and Anke, T. 1998.Characterization of laccases and peroxidases from wood rotting fungi (family Coprinaceae). Appl. Environ. Microbiol., 64(5): 1601-1606.

Hou, H., Zhou, J., Wang, J., Du, C., and Yan, B. 2004. Enhancement of laccase production by Pleurotusostreatusand its use for the decolorization of anthraquinone dye. Process Biochem., 39(11): 1415-1419.

Kiiskinen, L. L., Ratto, M., and Kruus, K. 2004.Screening for novel laccase producing microbes. J. Appl. Microbiol., 97: 640-646.

Kitamura, S., Suzuki, T., Sanoh, S., Kohta, R., Jinno, N., Sugihara, K., Yoshihara, S., Fujimoto, N., Watanabe, H., and Ohta, S. 2005. Comparative Study of the endocrine-disrupting activity of bisphenol A and 19 related compounds. Toxicol. Sci., 84: 249-259.

Kuwahara, M., Glenn, J., Morgan, M., and
Gold, M.S. 1984.Separation and characterization of two extracellular $\mathrm{H}_{2} \mathrm{O}_{2}$-dependent oxidases from ligninolytic cultures of Phanerochaete chrysosporium. FEBS Lett., 169: 247250.

Leatham, G. F., and Stahmann, M. A. 1981. Studies on the laccase of Lentinusedodes: specificity, localization and association with the development of fruiting bodies. J. General Microbiol., 125: $147-157$

Lee, S. M., Koo, B. W., Lee, S. S., Kim, M. K., Choi, D. H., Hong, E. J., Jeung, E. B., and Choi, I. G. 2004. Biodegradation of dibutyl phthalate by white rot fungi and evaluation on its estrogenic activity. Enzyme and Microbial Technol., 35: 417-423.

Lu, C., Wang, H., Luo, Y., and Guo, L. 2010. An efficient system for predelignification of Gramineous biofuel feedstock in vitro: application of a laccase from Pycnoporussanguineus H275. Process Biochem., 45: 11411147.

Orth, A.B., and Tien, M. 1995. Biotechnology of lignin degradation. In: Esser, K, Lemke, PA (eds) The Mycota. II. Genetics and biotechnology. Springer, Berlin Heidelberg, New York, pp 287302.

Placido, J., and Capareda, S. 2015. Ligninolytic enzymes: a biotechnological alternative for bioethanol production. Biores. Bioprocessing, 2: 23.

Pointing, S.B. 2001. Feasibility of bioremediation by white rot fungi. Appl. Microbiol. Biotechnol., 57: 20-33.

Salvachua, D., Prieto, A., Lopez-Abelairas, M., Lu-Chau, T., Martinez, A. T., and Martinez, M.J. 2011. Fungal pretreatment: an alternative in secondgeneration ethanol from wheat straw. Biores. Technol., 102: 7500-7506. 
Sandhu, D.K., and Arora, D.S. 1985. Laccase production by Polyporussanguineus under different nutritional and environmental conditions. Experientia, 41: 355-356.

Sasidhara, R., and Thirunalasundari, T. 2014. Lignolytic and lignocellulosic enzymes of Ganodermalucidum in liquid medium. European J. Experimental Biol., 4(2): 375-379.

Sivakami, V., Ramachandran, B., Srivathsan, J., Kesavaperumal, G., Smily, B., and Kumar, D.J.M. 2012.Production and optimization of laccase and lignin peroxidase by newly isolated Pleurotusostreatus LIG $19 . \quad J$. Microbiol. Biotechnol. Res., 2: 875-881.

Tien, M., and Kirt, T.K. 1983. Lignindegrading enzyme from the
Hymenomycetes

Phanerochaete chrysosporium burds. Sci., 221: 661663.

Tuomela, M., and Hatakka, A. 2011.Oxidative fungal enzymes for bioremediation. In: Moo-Young, M., Agathos, S. (Eds.), Comprehensive Biotechnology, second ed. Elsevier, Spain, pp. 183-196.

Wang, C., Sun, H., Li, Y., and Zhang, Q. 2009. Enzyme activities during degradation of polycyclic aromatic hydrocarbons by white rot fungus Phanerochaetechrysosporiumin soils. Chemosphere, 77: 733-738.

Wong, D.W.S. 2009. Structure and Action Mechanism of ligninolytic enzymes. Appl. Biochem. Biotechnol., 157: 174209.

\section{How to cite this article:}

Nikki Agrawal, Preeti Verma, Ravi Shankar Singh and Sushil Kumar Shahi. 2017. Ligninolytic Enzyme Production by White Rot Fungi Podoscypha elegans Strain FTG4. Int.J.Curr.Microbiol.App.Sci. 6(5): 2757-2764. doi: https://doi.org/10.20546/ijcmas.2017.605.309 